\title{
Grid Connected Fuel Cell Based Distributed Power Generation System
}

\author{
Sabha Raj Arya and Nunsavath Sharath Kumar \\ Department of Electrical Engineering, S.V. National Institute of Technology, \\ Surat-395007, India \\ E-mail:sabharaj1@gmail.com; mean.machine3011@gmail.com
}

Received 26 February 2017; Accepted 21 August 2017;

Publication 13 September 2017

\begin{abstract}
Fuel cell based power generation is emphasized due to its capability of supplying electricity in the areas where there are hardly any source of conventional or non-conventional power generating options to adopt. Moreover, the added advantage is that it can be used during peak loads. Fuel cell based power generation is well known due to its clean operation, transportability, suitability and flexibility for power generation. This paper gives the outlook of modeling of a fuel cell power generation system, a multilevel inverter and their control algorithms. The design system is used in isolated loads as well as grid connected system. Different carrier signals have been used with two different modulating signals for multilevel inverter for lowest Total Harmonic Distortion (THD) in the output using seven levels and eleven level inverters. The inverter output is fed to consumer loads. The MATLAB/SIMULINK software is used for modeling this system. The developed fuel cell based distributed power generation system worked satisfactorily, when it is connected to grid and used in isolated mode or hybrid mode.
\end{abstract}

Keywords: Fuel cell, Multilevel inverter, modulation index, modulation schemes, Total harmonic distortion (THD).

Journal of Green Engineering, Vol. 7, 285-310.

doi: 10.13052/jge1904-4720.71212

(c) 2017 River Publishers. All rights reserved. 


\section{Introduction}

Fuel cell is widely considered to be a clean and productive entity and it is presently under rigorous research and development by many researcher and manufacturers for both stationary and mobile applications [1]. It has added advantage of environment friendly and non-polluting energy which converts chemical energy into electrical energy directly [2]. In contrast to conventional power generation system, fuel cell produces low chemical pollutants and it is integrated using adaptive control in hybrid power generation system [3]. Fuel cells can be called as electrochemical devices that convert chemical energy directly to electricity, without any rotating parts as in case of conventional systems. The found deep inside the earth which is limited, either in the form of solid, gas or liquid are called as nonrenewable resources $[4,5]$. In literature [6], a power inverter is useful as power conditioner in fuel cell based distributed power generation. Conversely the fuel cells are projected up as a favourable alternative for their high efficiency, low emissions, noise free operation, mass, substantiality in space, mobility and exclusively stand alone applications.

Since past decades power electronics field is emerging as a centre of attraction in industries and various type of multilevel converters have received due attention in application of distributed power generation system (DGPS). It can be effectively used in DGPS where improved AC voltage waveform is obtained from DC source as fuel cells, solar cells or batteries etc. [7]. The output voltage from the inverter can be supplied directly to a load or to an established grid without any voltage unbalance issue. The multilevel inverters offer several benefits as compared to conventional inverters that is two-level pulse width modulation (PWM), such as to utilize at high voltage with low dv/dt per high switching efficiency etc. [8]. The three types of multilevel inverters are cascade, diode-clamped and flying capacitor multilevel inverter [9]. A review on various carrier based PWM technique for multilevel converter is discussed in the literature [10]. The output wave forms of actual inverter are quasi kind of waveform that is non-sinusoidal and have some amount of harmonics in it. For low and medium power application, square wave or quasi-square wave form of voltage may be allow but for highpower operation sine wave must be provided with low distortion. The harmonic components in the output of inverter can be removed either by making use of a filtering circuit or PWM schemes. Conventional inverters have certain limitations which may include common mode voltage, distortion in output wave form, capacitor voltage equalization, cost and control algorithm etc. [11-14]. 
In these references, a multilevel inverter supplying DC source is fed to various applications such traction system, electrical drives and power filter etc. These are suitable alternatives for high power and medium voltage applications.

Fuel cells can be considered as a battery which never discharges as long as there is a continuous supply of hydrogen and oxygen. Nowadays, Phosphoric acid fuel cell is accessible in market to generate power in the range of $200 \mathrm{~kW}$. Moreover, molten carbonate and solid oxide fuel cells are in initial stage of advancement [15]. The recent research studies about the fuel cells is concentrated on the polymer electrolyte membrane (PEM) fuel cells. The modeling of micro turbine and development of various type of fuel are discussed in literature [16]. In this reference, it is used deign microgrid based on photovoltaic and wind, battery as source including energy management system. Energy is a key factor of the synergy between environment and its citizens and is termed as a major input for the habitat as well as ecological balance. In the reference [17], the waveform distortion in various level of cascade type multilevel converter is discussed for energy saving in industrial application. Recently, various solutions to the present environmental imbalance like hazardous pollutant emissions have been developed. For localities to achieve sustainable development, attempt should be made to develop these new technologies. Hydrogen production in renewable energy can serve a potential competence to the present scenario. Latest fuel cell technologies can enhance the environmentally related problems to be sort out by replacing it with conventional methods [18]. According to Midilli, increasing concerns related to urban air pollution, climate change and energy security will anticipate the transition to "hydrogen economy". It indicates that both high and low-temperature derivatives of new hydrogen powered fuel cell technologies are considered to be one of the standard supports of a future perpetual means of energy production system. Barreto examine prospect of fuel cells and to develop continual hydrogen based solutions for the world-wide energy system [19-21]. Fuel cells nowadays are getting the attention towards it because of their distinct characteristic of producing low pollutants and high theoretical efficiency. Today, Fuel Cell categorizes the usage of fuel in three major areas: portable, stationary power generation, and transportation. Fuel Cell today interpret fuel cells for transport as a unit that furnishes propulsive power to an automobile, directly or indirectly. It involves the technological applications like goods lifting vehicles like Forklift trucks etc. The main mechanism for fuel cells in portable applications are off-grid operation, long run as compared with conventional batteries, rapid recharging, essential weight reduction, reliability, and low operating costs. 
This paper gives a prospect of a simple fuel cell model and a comparison of total harmonics distortion in seven level and eleven level multilevel inverter. After fuel cell, the output power is fed to multilevel inverter (MLI) of three different configurations [22]. They are operated in different switching patterns with different carrier frequency signal which are phase disposition (PD), variable frequency carrier band (VFCB), phase opposition disposition (POD), phase shift (PS), alternate phase opposition disposition (APOD), and carrier overlapping $(\mathrm{CO})$. All these carrier frequency signals are considered with all the three different multilevel inverter with fixed carrier frequency signal and the results are compared. Here it is considered for three different amplitude modulation index of $\mathrm{m}_{\mathrm{a}}=0.8,1$ and 1.8 along with change in magnitude of the output voltage and THD are observed. The lowest THD producing multilevel inverter is selected while considering the modulating signal to be sinusoidal, then this modulating sinusoidal signal is replaced with third harmonic injected signal which gives better results. Then this output AC signal can be operated either in a grid-connected mode or stand-alone mode. Considering the output of multilevel inverter output i.e. AC, this output is fed to isolated load and Grid, to see their performance. Here in this case inverted output voltage is fed to Interconnected Grid system considering three cases which involves isolated load, fuel cell wholly feeding the power to the load in a grid and the power shared by the load from the fuel cell is fed to the inverter and the grid system. This paper focuses on load/grid connected fuel cell based power generating system which can also be utilized for the commercial units i.e. in apartments, shopping malls etc. as a backup power. This backup power source can provide energy at reasonable per unit cost and will be efficient. In order to demonstrate the given model, simulation in MATLAB/SIMULINK environment has been carried out.

\section{System Configuration and Modulation Schemes}

A fuel cell based power generation system is developed with and without grid connection. The output of this system is DC voltage which is fed to different topologies of multilevel inverter to convert DC to AC supply. The developed system is shown in the Figure 1. In this system, after extracting pure hydrogen from fuel reformer it is supplied to fuel cell with oxygen fed from either side which in turn produces electricity in DC with residue as water and some heat. This inverted AC output is fed to grid as well as connected consumer load across it as shown in the Figure 1. This AC supply is fed to grid and an isolated load to observe the power supplying capability of fuel cell under different load condition and load sharing between grid and fuel cell is analyzed. 


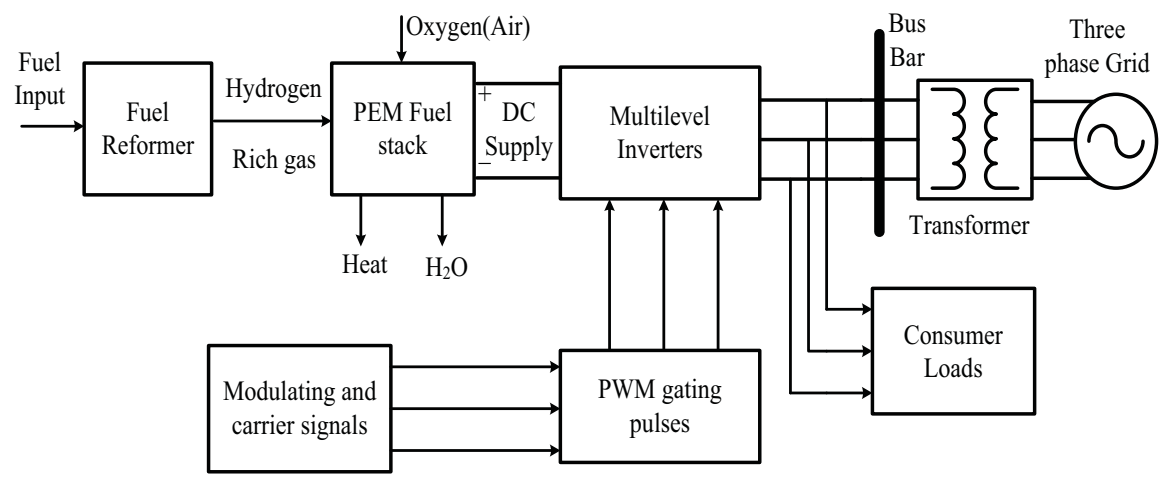

Figure 1 Block Diagram of fuel cell based distributed power generation system.

A simulation model is designed by keeping modulating signal as sinusoidal which is synchronized with grid phase sequence and changing different carrier signals such as phase disposition (PD), alternate phase opposition disposition (APOD), carrier overlapping (CO), phase opposition disposition (POD), variable frequency carrier bands (VFCB) and phase shift (PS). The simulations are carried out with these techniques for all three types of multilevel inverter for seven and eleven levels. Other important components are discussed below.

\subsection{Fuel Cell}

A fuel cell is a reactor in which fuel and an oxidizer react electrochemically for generation of electricity and a number of byproducts. A proton exchange membrane (PEM) hydrogen-oxygen fuel cell uses hydrogen as its main fuel and oxygen as its oxidizer. The byproducts of it include heat and water. The "gaseous voltaic cell" built by William Grove generated electricity and water as byproduct from reaction of hydrogen and oxygen $[1,2,5,15,21]$. The fuel cell used porous platinum electrodes and sulfuric acid as an electrolyte. William White Jacques, who substituted phosphoric for sulfuric acid as the electrolyte, coined the term "Fuel Cell". There have been many significant attempts to build fuel cells for many years. Here a brief focus is given on modeling a simple proton exchange membrane (PEM) fuel cell. Figure 2 shows the basic fuel cell components. This paper deals with the postulate behind the fuel cell derived from mathematical and electrochemical point of view. A simple general model for the fuel cell that could help to understand the function of the fuel cell is developed using simulink. 


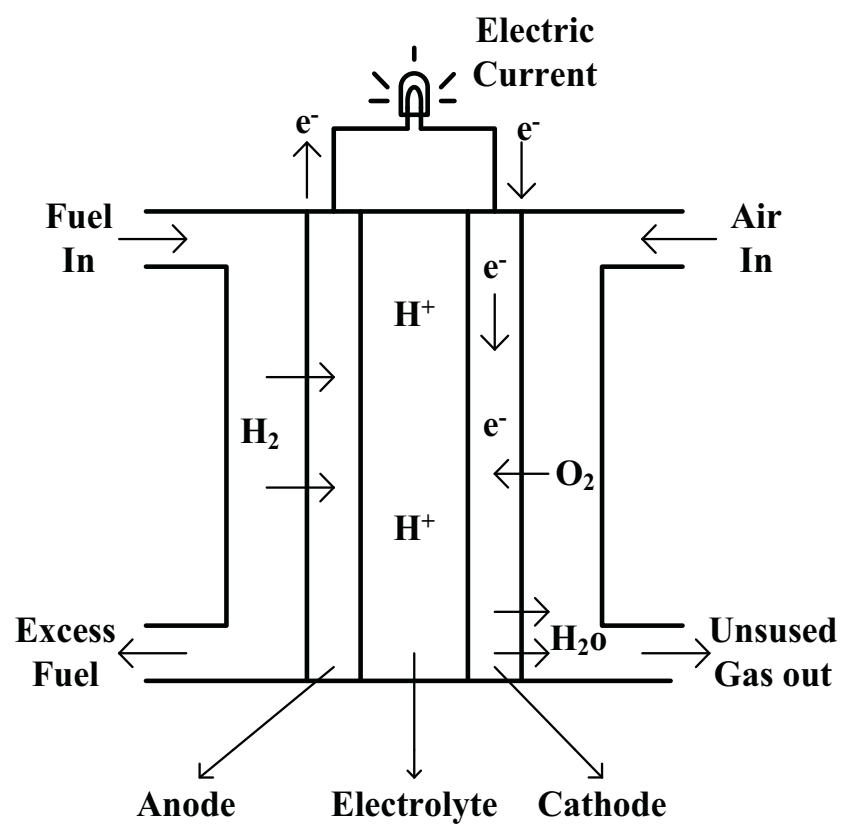

Figure 2 Basic fuel cell components.

The operation of the fuel cell is best described by the half-cell reactions at the anode and cathode electrodes. The role of electrodes and electrolytes in enabling this reaction is also as important as the reactions themselves. At the anode, hydrogen dissociates at the catalyst producing $\mathrm{H}+$ ions and electrons. The half-cell reaction is

$$
2 \mathrm{H}_{2} \Rightarrow 2 \mathrm{H}^{+}+2 e^{-}
$$

The protons thus formed move through the electrolytes to react with oxygen at the cathode producing water. The electrons formed at the anode are transferred by the external circuitry to the cathode to supply the elections required in this reaction. The cathode half cell reaction is

$$
\frac{1}{2} \mathrm{O}_{2}+2 e^{-}+2 \mathrm{H}^{+} \Rightarrow \mathrm{H}_{2} \mathrm{O}
$$

The change in Gibbs free energy is a energy produced in a chemical reaction. The Gibbs free energy of formation is analogous to mechanical potential energy. Thus, a change in this energy is the energy released. As mentioned earlier, the basic operation of the fuel cell involves the transfer 
of two electrons per mole from the anode to the cathode producing a water molecule. The work done in this process is the same as the change in the Gibbs free energy of formation. That is, mathematically

$$
\Delta g_{f}=-2 D e E=-(2 C E)
$$

Where ' $\Delta \mathrm{g}_{\mathrm{f}}$ ' is the change in the Gibbs free energy, ' $\mathrm{E}$ ' is the EMF of the PEM fuel cell, ' $\mathrm{D}$ ' is Avogadro's number (the number of molecules in one mole), "C" is Faraday's constant and 'e' the charge of the electron. So the open circuit voltage of the fuel cell is given by

$$
E^{0}=\frac{\Delta g_{f}}{2 C}
$$

The Nernst equation gives the relationship between the actual voltage produced at different pressures and temperatures of the products as well as the reactants and standard potential for a cell reaction

Nernst Equation:

$$
E=E^{0}+\frac{U T}{2 C} \ln \frac{P_{\text {reactant }}}{P_{\text {product }}}
$$

Where ' $\mathrm{P}_{\text {reactant }}$ ' is the product of partial pressures of the reactants and ' $\mathrm{P}_{\text {product }}$ ' is the product of the partial pressures of the products produced in the cell reaction. All pressures are expressed in bars. ' $C$ ' is Faraday's constant, ' $U$ ' is the universal gas constant and ' $T$ ' the operating temperature of the fuel cell.

The power lost by the fuel cell depends on the resistance of the membrane, the number of moles of Oxygen reacting in the fuel cell and the actual voltage of the fuel cell. The difference in die voltage from die ideal voltage determines the amount of power loss due to die over voltages produced in die fuel cell Major causes of this drop are activation losses, internal currents, also called fuel crossover, ohmic losses and mass transportation losses, also called concentration losses.

$V=E^{0}+\frac{3 U T}{4 C} \ln \frac{P_{2}}{P_{1}}-\left(i+i_{n}\right) * R-A \ln \frac{\left(i+i_{n}\right)}{i_{0}}+B \ln \left(1-\frac{i+i_{n}}{i_{l}}\right)$

In this equation, ' $\mathrm{E}^{0}$ ' is the open circuit voltage, ' $\mathrm{R}$ ' is specific resistance, ' $i_{n}$ ' internal current density ' $i_{0}$ ' is exchange current density, ' $A$ ' is slope of Tafel curve, ' $\mathrm{B}$ ' is mass transfer over voltage constant, ' $\mathrm{i}_{1}$ ' is the limiting current density at the electrode. Typical values [2] for a PEM fuel cell constants are given in the Table 1 . 


\begin{tabular}{ll} 
Table 1 & Typical Values of Fuel Cell \\
\hline Constant & Typical Value \\
\hline$E$ & $1 \mathrm{~V}$ \\
$i_{n}$ & $2 \mathrm{mA.cm}{ }^{-2}$ \\
$r$ & $0.03 \Omega . \mathrm{cm}^{2}$ \\
$i_{0}$ & $0.067 \mathrm{mA.cm}$ \\
$A$ & $0.06 \mathrm{~V}$ \\
$B$ & $0.05 \mathrm{~V}$ \\
$i_{l}$ & $900 \mathrm{mA.cm}$ \\
\hline
\end{tabular}

\subsection{Multilevel Inverter}

Multilevel inverters are currently leading in the areas of high and medium power controlling systems due to its ability to reduce the total harmonic distortion without using any filter circuit as well as being economical and easy to implement. Basically the aim of a voltage source inverter (VSI) is to convert a constant $\mathrm{DC}$ voltage to $\mathrm{AC}$ voltage with variable magnitude and frequency. Its conversion provides a number of voltage levels accordingly as per the requirement thereby producing less distorted output voltage with multi-step kind of waveform nearly representing the sinusoidal AC output. It comprises of three different topologies of multilevel inverter. The principle of the sinusoidal PWM scheme depends on the sinusoidal modulating waves $\left(\mathrm{V}_{\mathrm{m}}\right)$ and a triangular carrier wave $\left(\mathrm{V}_{\mathrm{cr}}\right)$. Inverter's fundamental-frequency component output voltage can be varied by amplitude modulation index [22].

$$
m_{a}=\frac{V_{m}}{V_{c r}}
$$

Where $\mathrm{V}_{\mathrm{m}}$ and $\mathrm{V}_{\mathrm{cr}}$ are the peak values of the modulating and carrier waves, respectively. The amplitude modulation index $\mathrm{m}_{\mathrm{a}}$ can be adjusted by varying $\mathrm{V}_{\mathrm{m}}$ while keeping $\mathrm{V}_{\mathrm{cr}}$ fixed. The frequency modulation index is defined by

$$
m_{f}=\frac{f_{c r}}{f_{m}}
$$

Where $f_{m}$ and $f_{c r}$ are the frequencies of the modulating wave and carrier wave, respectively.

\subsubsection{Cascaded H-Bridge (CHB) Multilevel Inverter}

This particular multilevel inverter is used to produce high power by connecting power electronic switches in series with number of low valued DC source to convert the DC to a staircase kind of AC output at its output terminal. 
The carrier-based modulation techniques for multilevel inverters can be mainly arranged into two broad classification. First is phase-shifted and second is level-shifted modulations. These modulation schemes can be applied to all the three topologies of inverters [22]. Commonly, a multilevel inverter with $\mathrm{k}$ voltage levels needs $(k-1)$ triangular carriers signals. In the phaseshifted carrier modulation, all the triangular carriers have same peak-to-peak amplitude and same frequency, the only difference in phase shift modulation is between any two adjacent carrier waves there is a phase shift and it is given by

$$
\varphi_{c r}=\frac{360}{(k-1)}
$$

Alike to the phase-shifted modulation, an $k$-level inverter using level-shifted carrier modulation scheme requires $(k-1)$ triangular carriers, all of them with the same amplitude and frequency. The $(k-1)$ triangular carriers are vertically arranged such that the bands they occupy are one upon one to get displaced by certain amplitude. The frequency modulation index is given by $\mathrm{m}_{\mathrm{f}}=\mathrm{f}_{\mathrm{cr}} / \mathrm{f}_{\mathrm{m}}$, which is the same as that of the phase-shifted modulation technique but the amplitude modulation index is defined as,

$$
m_{a}=\frac{V_{m}}{V_{c r}(k-1)}
$$

Where $\mathrm{V}_{\mathrm{m}}$ the peak magnitude of the modulating wave and $\mathrm{V}_{\mathrm{cr}}$ is the peak magnitude of each carrier wave.

Figure 3 shows 5 level cascade H-bridge inverter with one leg with its switching pattern mentioned in the Table 2 as a sample to understand the 7 and 11 level inverter of same kind. In phase-shifted modulation, the switching frequency of the device is equal to the carrier frequency. Furthermore, the switching frequency is not the same for the devices in different H-bridge cells. In general, the switching frequency of the inverter using the level-shifted modulation is not equal to the carrier frequency. In addition to the unequal device switching frequencies, the conduction time of the devices is unevenly distributed. To equally distribute the conduction and switching losses, among the H-bridge cells the switching pattern should be rotated [22]. Advantages of this inverter are it needs less number of devices compared to all multilevel converters to attain the same number of voltage levels, the control of the DC buses is easy and compatibility of control can be attained. In contrast to the diode clamped and capacitor clamped inverter where the individual phase legs must be adjusted by a central controller, the full-bridge inverters of a cascaded configuration can be adjusted separately. 


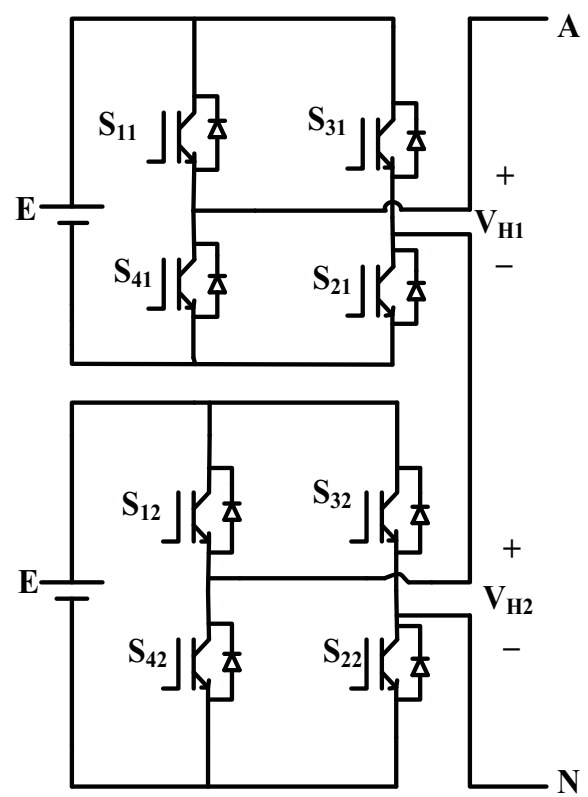

Figure 3 Five level Cascade H-Bridge inverter with one leg.

Table 2 Switching Pattern for 5 level Cascade H-Bridge inverter

\begin{tabular}{lcccccc}
\hline Output & \multicolumn{5}{c}{ Switching State } \\
\cline { 2 - 7 } Voltage $V_{A N}$ & $S_{11}$ & $S_{31}$ & $S_{12}$ & $S_{32}$ & $V_{H 1}$ & $V_{H 2}$ \\
\hline $2 \mathrm{E}$ & 1 & 0 & 1 & 0 & $\mathrm{E}$ & $\mathrm{E}$ \\
\hline $\mathrm{E}$ & 1 & 0 & 1 & 1 & $\mathrm{E}$ & 0 \\
& 1 & 0 & 0 & 0 & $\mathrm{E}$ & 0 \\
& 1 & 1 & 1 & 0 & 0 & $\mathrm{E}$ \\
& 0 & 0 & 1 & 0 & 0 & $\mathrm{E}$ \\
\hline 0 & 0 & 0 & 0 & 0 & 0 & 0 \\
& 0 & 0 & 1 & 1 & 0 & 0 \\
& 1 & 1 & 0 & 0 & 0 & 0 \\
& 1 & 1 & 1 & 1 & 0 & 0 \\
& 1 & 0 & 0 & 1 & $\mathrm{E}$ & $-\mathrm{E}$ \\
& 0 & 1 & 1 & 0 & $-\mathrm{E}$ & $\mathrm{E}$ \\
\hline$-\mathrm{E}$ & 0 & 1 & 1 & 1 & $-\mathrm{E}$ & 0 \\
& 0 & 1 & 0 & 0 & $-\mathrm{E}$ & 0 \\
& 1 & 1 & 0 & 1 & 0 & $-\mathrm{E}$ \\
& 0 & 0 & 0 & 1 & 0 & $-\mathrm{E}$ \\
\hline$-2 \mathrm{E}$ & 0 & 1 & 0 & 1 & $-\mathrm{E}$ & $-\mathrm{E}$ \\
\hline
\end{tabular}




\subsubsection{Diode Clamped Multilevel Inverters}

The diode-clamped multilevel inverter utilizes clamping diodes and cascaded DC capacitors to produce AC voltage waveforms with multi-levels. The inverter can be normally configured in three, four, or five-level topologies, but only the three-level inverter has found extensive application in high-power and medium-voltage (MV) drives. The main features of this inverter include minimal $d v / d t$ and THD in its output voltages. Moreover, the inverter can be used to attain a desired voltage level without need of switching devices in sequence in the drive. Figure 4 shows 5 level cascade H-bridge inverter with one leg with its switching pattern mentioned in the Table 3 as a sample and simpler to understand the 7 and 11 level inverter of same kind.

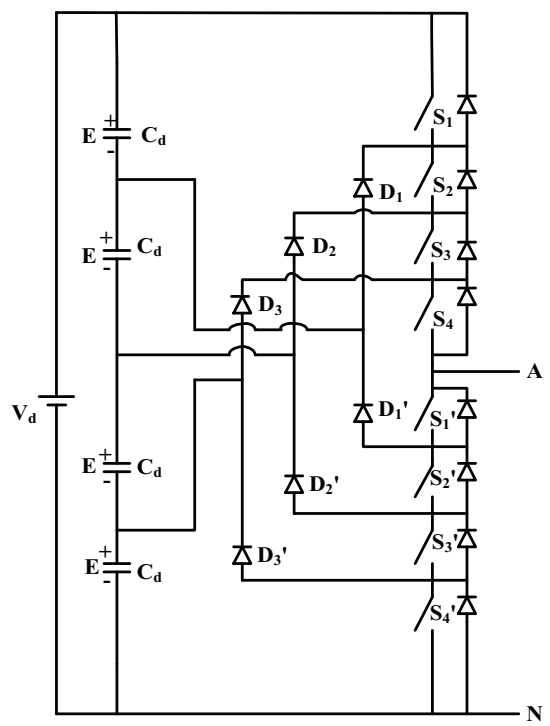

Figure 4 Five level diode clamped inverter with one leg.

Table 3 Switching Pattern for 5 level diode clamped inverter

\begin{tabular}{lcccccccc}
\hline Output & \multicolumn{7}{c}{ Switching State } \\
\cline { 2 - 9 } Voltage $V_{A N}$ & $S_{1}$ & $S_{2}$ & $S_{3}$ & $S_{4}$ & $S_{1}^{\prime}$ & $S_{2}^{\prime}$ & $S_{3}^{\prime}$ & $S_{4}^{\prime}$ \\
\hline 4E & 1 & 1 & 1 & 1 & 0 & 0 & 0 & 0 \\
$3 \mathrm{E}$ & 0 & 1 & 1 & 1 & 1 & 0 & 0 & 0 \\
$2 \mathrm{E}$ & 0 & 0 & 1 & 1 & 1 & 1 & 0 & 0 \\
$\mathrm{E}$ & 0 & 0 & 0 & 1 & 1 & 1 & 1 & 0 \\
0 & 0 & 0 & 0 & 0 & 1 & 1 & 1 & 1 \\
\hline
\end{tabular}


Advantages of this inverter are it produces low harmonic content in its output, it is efficient for fundamental frequency switching and the complete phase divides the common DC bus, which minimizes the capacitance need of the converter.

\subsubsection{Multilevel Flying Capacitor Inverter}

Flying capacitor inverter utilizes capacitors to restrict the voltage of the power devices. The basic configuration of the flying capacitor multilevel inverter is similar to that of a diode clamped multilevel inverter except that the capacitors are made to divide the input DC voltage. Figure 4 shows a five level flying capacitor multilevel inverter. The switching states in this inverter are similar to that of a diode clamped multilevel inverter. That means for each output voltage level 4 switches should be on for five level inverter shown in Figure 5. Table 4 shows the switching states for a 5-level flying capacitor clamped multilevel inverter.

Advantages of this inverter are in contrast to the diode clamped configuration in which the series string of capacitors divide the same voltage, here in the capacitor-clamped voltage source converter the capacitors are charged to different voltage levels within the phase leg, large number of capacitors allows the inverter to ride through minimal duration of outages and deep

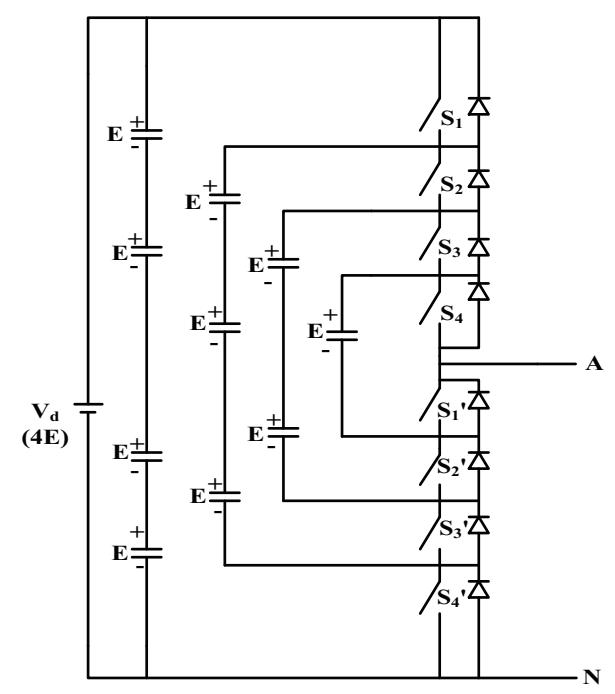

Figure 5 Five level flying capacitor inverter with one leg. 
Table 4 Switching Pattern for 5 level flying capacitor inverter

\begin{tabular}{lcccc}
\hline Output & \multicolumn{4}{c}{ Switching State } \\
\cline { 2 - 5 } Voltage $V_{A N}$ & $S_{1}$ & $S_{2}$ & $S_{3}$ & $S_{4}$ \\
\hline $4 \mathrm{E}$ & 1 & 1 & 1 & 1 \\
\hline $3 \mathrm{E}$ & 1 & 1 & 1 & 0 \\
& 0 & 1 & 1 & 1 \\
& 1 & 0 & 1 & 1 \\
& 1 & 1 & 0 & 1 \\
\hline $2 \mathrm{E}$ & 1 & 1 & 0 & 0 \\
& 0 & 0 & 1 & 1 \\
& 1 & 0 & 0 & 1 \\
& 0 & 1 & 1 & 0 \\
& 1 & 0 & 1 & 0 \\
& 0 & 1 & 0 & 1 \\
\hline $1 \mathrm{E}$ & 1 & 0 & 0 & 0 \\
& 0 & 1 & 0 & 0 \\
& 0 & 0 & 1 & 0 \\
& 0 & 0 & 0 & 1 \\
\hline 0 & 0 & 0 & 0 & 0 \\
\hline
\end{tabular}

voltage sags and reactive power flow can be managed, number of voltage levels can be attained without the necessity of the transformer. This helps in reducing the cost of the converter and power losses as well as the saving the clamping diodes.

\subsection{Comparison between the Phase and Level Shifted PWM Schemes}

Multi-carrier PWM scheme works on sampling of reference or modulating signal that is normally a sinusoidal signal with high frequency triangular signal, here the same frequency of the sinusoidal signal i.e. modulating signal can be observed at the output waveform of the converter. The modulating signal is compared with a high frequency triangular signals of different pattern. To compare the operation of phase and level-shifted modulation schemes, it is supposed that the average switching frequency of the devices is the equal for both the schemes. The output voltage produced by the phase-shifted modulation is nearly identical saving a small phase displacement between them. All the solid-state devices are operated at the same conduction time and switching frequency irrespective of when it is likely to be operated. However the output voltages produced by the level-shifted scheme are equal to zero at times and thus no switching occurs at the same time periods. Table 5 provides a brief comparison between phase and level shifted PWM schemes. 
Table 5 Comparison between the Phase and Level shifted PWM schemes

\begin{tabular}{llll}
\hline Sr. No. & Comparison & $\begin{array}{l}\text { Phase-Shifted } \\
\text { Scheme }\end{array}$ & $\begin{array}{l}\text { Level-Shifted } \\
\text { Scheme }\end{array}$ \\
\hline 1 & Switching frequency & $\begin{array}{l}\text { Same for all } \\
\text { switches }\end{array}$ & Different \\
\hline 2 & Switch conduction period & $\begin{array}{l}\text { Same for all } \\
\text { switches }\end{array}$ & Different \\
\hline 3 & $\begin{array}{l}\text { Rotating of switching } \\
\text { patterns }\end{array}$ & No needed & Needed \\
\hline 4 & Line-to-line voltage (THD) & Good & Better \\
\hline
\end{tabular}

\section{Results and Discussion}

A MATLAB based model of multilevel converter is developed and its steady state and dynamic performances are observed using SIMULINK and Sim Power System (SPS) toolboxes using different PWM techniques and different level of converters. The performance parameters are discussed at different modulation index with constant carrier frequency. The output of the inverter is fed to the consumer loads with grid and without grid connection. The observed performance of the developed system is discussed below with and without grid supply.

\subsection{Performance of Multilevel Inverter with Various PWM Schemes}

Table 6(a-f) show the THD profile for all the three different multilevel inverter topologies with both phase shifted and level shifted carrier frequency signals used for simulation separately for 7 and 11 level inverters considering sinusoidal signal as the modulating signal. Table $6(\mathrm{a}-\mathrm{c})$ show THD values of seven level multilevel inverter with different carrier signals. It can be observed that after considering $\mathrm{m}_{\mathrm{a}}$ (Amplitude modulation index) variation from 0.8, 1 and 1.8 in all the three type of multilevel inverter, the minimum THD is observed in the case phase disposition as the carrier signal and maximum THD is seen when carrier signal is phase opposition disposition for $\mathrm{m}_{\mathrm{a}}$ of 0.8 and 1. For over-modulation that is $\mathrm{m}_{\mathrm{a}}$ of 1.8 , it is observed that carrier overlapping as the carrier signal gives maximum THD. Similarly, Table 6(d-f) show THD values for eleven level multilevel and it is found that eleven level diode clamped inverter gives the least THD at the level of 5.86\% with the over modulation of $\mathrm{m}_{\mathrm{a}}=1.8$ in phase disposition carrier based scheme and other two multilevel inverter gives equal THD with slightly greater than diode clamped inverter. From discussion, it is observed that in condition of under 
Table 6 Percentage THD Obtained for Different Multilevel Inverter Configuration with Different Carrier Frequency Signals with Different Amplitude Modulation Index

\begin{tabular}{llcccccc}
\hline \multicolumn{7}{c}{ (a) 7 Level Multilevel Inverter $\left(\mathrm{m}_{\mathrm{a}}=0.8, \mathrm{~m}_{\mathrm{f}}=60, \mathrm{f}_{\mathrm{cr}}=3000 \mathrm{~Hz}, \mathrm{~V}_{\mathrm{m}}=5\right)$} \\
\hline \multirow{2}{*}{ Sr. No. } & $\begin{array}{l}\text { Inverter } \\
\text { Configuration }\end{array}$ & PD & POD & APOD & PS & VFCB & CO \\
\hline 1 & $\begin{array}{l}\text { Cascade } \\
\text { Connected }\end{array}$ & 13.23 & 22.17 & 19.41 & 19.73 & 16.16 & 14.78 \\
& Diode Clamped & 13.32 & 22.49 & 19.23 & - & 16 & 14.71 \\
\hline 2 & 13.22 & 22.15 & 19.39 & 19.74 & 16.15 & 14.78 \\
\hline 3 & $\begin{array}{l}\text { Flying } \\
\text { Capacitor }\end{array}$ & & & & & & \\
\hline
\end{tabular}

(b) 7 Level Multilevel Inverter $\left(\mathrm{m}_{\mathrm{a}}=1, \mathrm{~m}_{\mathrm{f}}=60, \mathrm{f}_{\mathrm{cr}}=3000 \mathrm{~Hz}, \mathrm{~V}_{\mathrm{m}}=6\right)$

\begin{tabular}{llcccccc}
\hline \multirow{2}{*}{ Sr. No. } & $\begin{array}{l}\text { Inverter } \\
\text { Configuration }\end{array}$ & PD & POD & APOD & PS & VFCB & CO \\
\hline 1 & Cascade & 10.72 & 14.99 & 14.64 & 14.92 & 13.72 & 14.47 \\
& Connected & & & & & & \\
\hline 2 & Diode Clamped & 10.76 & 15.07 & 14.73 & - & 13.72 & 14.28 \\
\hline 3 & $\begin{array}{l}\text { Flying } \\
\text { Capacitor }\end{array}$ & 10.72 & 14.99 & 14.65 & 14.92 & 13.73 & 14.47 \\
& & & & & & \\
\hline
\end{tabular}

(c) 7 Level Multilevel Inverter $\left(\mathrm{m}_{\mathrm{a}}=1.8, \mathrm{~m}_{\mathrm{f}}=60, \mathrm{f}_{\mathrm{cr}}=3000 \mathrm{~Hz}, \mathrm{~V}_{\mathrm{m}}=11\right)$

\begin{tabular}{lllllllc}
\hline & & & & & & \\
Sr. No. & $\begin{array}{l}\text { Cnverter } \\
\text { Configuration }\end{array}$ & PD & POD & APOD & PS & VFCB & CO \\
\hline 1 & $\begin{array}{l}\text { Cascade } \\
\text { Connected }\end{array}$ & 8.51 & 8.56 & 8.65 & 8.52 & 8.65 & 18.09 \\
& & & & & & \\
\hline 2 & Diode Clamped & 8.40 & 8.46 & 8.59 & - & 8.56 & 17.96 \\
\hline 3 & $\begin{array}{l}\text { Flying } \\
\text { Capacitor }\end{array}$ & 8.51 & 8.65 & 8.52 & 8.52 & 8.66 & 18.08 \\
& & & & & & \\
\hline
\end{tabular}

(d) 11 Level Multilevel Inverter $\left(\mathrm{m}_{\mathrm{a}}=0.8, \mathrm{~m}_{\mathrm{f}}=60, \mathrm{f}_{\mathrm{cr}}=3000 \mathrm{~Hz}, \mathrm{~V}_{\mathrm{m}}=8\right)$ Inverter

\begin{tabular}{llllllll} 
Sr. No. & Configuration & PD & POD & APOD & PS & VFCB & CO \\
\hline 1 & $\begin{array}{l}\text { Cascade } \\
\text { Connected }\end{array}$ & 8.27 & 11.58 & 11.96 & 12.24 & 10.48 & 9.39 \\
& & & & & & \\
\hline 2 & Diode Clamped & 8.30 & 11.64 & 12.27 & - & 10.67 & 9.30 \\
\hline 3 & $\begin{array}{l}\text { Flying } \\
\text { Capacitor }\end{array}$ & 8.27 & 11.57 & 11.96 & 12.23 & 10.46 & 9.40 \\
& & & & & & \\
\hline
\end{tabular}

(e) 11 Level Multilevel Inverter $\left(\mathrm{m}_{\mathrm{a}}=1, \mathrm{~m}_{\mathrm{f}}=60, \mathrm{f}_{\mathrm{cr}}=3000 \mathrm{~Hz}, \mathrm{~V}_{\mathrm{m}}=10\right)$ Inverter

\begin{tabular}{llllllll} 
Sr. No. & Configuration & PD & POD & APOD & PS & VFCB & CO \\
\hline 1 & Cascade & 6.84 & 9.47 & 8.52 & 8.59 & 7.71 & 9.84 \\
& Connected & & & & & & \\
\hline 2 & Diode Clamped & 6.95 & 9.57 & 8.43 & - & 7.61 & 9.62 \\
\hline 3 & $\begin{array}{l}\text { Flying } \\
\text { Capacitor }\end{array}$ & 6.84 & 9.47 & 8.52 & 8.59 & 7.71 & 9.84 \\
& & & & & & \\
\hline
\end{tabular}


Table 6 Continued

\begin{tabular}{lllllllc}
\hline \multicolumn{7}{c}{ (f) 11 Level Multilevel Inverter $\left(\mathrm{m}_{\mathrm{a}}=1.8, \mathrm{~m}_{\mathrm{f}}=60, \mathrm{f}_{\mathrm{cr}}=3000 \mathrm{~Hz}, \mathrm{~V}_{\mathrm{m}}=18\right)$} \\
\hline Sr. No. & $\begin{array}{l}\text { Inverter } \\
\text { Configuration }\end{array}$ & PD & POD & APOD & PS & VFCB & CO \\
\hline 1 & $\begin{array}{l}\text { Cascade } \\
\text { Connected }\end{array}$ & 5.89 & 5.90 & 6.01 & 5.87 & 5.96 & 16.52 \\
\hline 2 & Diode Clamped & 5.86 & 5.95 & 6.04 & - & 5.96 & 16.31 \\
\hline 3 & $\begin{array}{l}\text { Flying } \\
\text { Capacitor }\end{array}$ & 5.90 & 5.92 & 6.01 & 5.87 & 5.95 & 16.52 \\
& & & & & & & \\
\hline
\end{tabular}

and moderate modulation i.e. for $\mathrm{m}_{\mathrm{a}}=0.8$ and $\mathrm{m}_{\mathrm{a}}=1$, the 11 level diode clamped inverter is giving more THD when it is compared with the other two multilevel inverter with the fixed carrier frequency of $3000 \mathrm{~Hz}$.

So by considering diode clamped inverter, the simulations are carried on it by using third harmonic injected signal as modulating signal instead of sinusoidal signal. This simulation is performed for all the three inverters by taking the phase disposition as the carrier signal and the results are observed. Table 7(a) shows THD comparison between sinusoidal signal and third harmonic injected signal as the modulating signal for seven level inverter. Similarly, Table 7(b) shows the comparison of THD in eleven level inverter considering sinusoidal and third harmonic injected signal separately as the modulating signal. As it can seen that by using third harmonic injected signal as modulating signal the THD is reduced significantly. As an added advantage it can be seen that lower THD is obtained for reduced over modulation which is observed a lower THD of $4.94 \%$ at $\mathrm{m}_{\mathrm{a}}=1.2$ compared to $\mathrm{m}_{\mathrm{a}}$ of 1.8. From above discussion, it concludes that by using third harmonic injected modulating signal, lower THD is obtained with significant reduction in amplitude modulation index and therefore using this scheme, the level of fundamental voltage is increased with dominant harmonics.

Figure 6(a, b) shows the waveform of cascade bridge inverter output voltage and output current with harmonic spectra. In these figures, the value of harmonic in output voltage and output current is observed 5.2\% and $4.42 \%$. Figure $7(a, b)$ shows the spectra of output voltage and output current for a diode clamped inverter with observed THD of $4.94 \%$ and $4.33 \%$ respectively. Figure $8(a, b)$ shows the spectra of output voltage and output current for flying capacitor inverter with an observed THD of $6.26 \%$ and $6 \%$ respectively. After replacing the sine modulating signal with Third harmonic injected signal, the THD is reduced to $4.94 \%\left(\mathrm{~m}_{\mathrm{a}}=1.2, \mathrm{f}_{\mathrm{cr}}=3000 \mathrm{~Hz}, \mathrm{~m}_{\mathrm{f}}=60, \mathrm{~V}_{\mathrm{m}}=12\right)$ when compared with THD of $5.68 \%$ in the earlier case of pure sinusoidal signal as its modulating signal. It is observed from Table 7(b). 
Grid Connected Fuel Cell Based Distributed Power Generation System 301

Table 7 Comparison of Percentage THD using Sinusoidal and Third Harmonic Injected Modulating Signal

\begin{tabular}{llll}
\hline & \multicolumn{2}{c}{ (a) 7 Level Multilevel Inverter $\left(\mathrm{m}_{\mathrm{f}}=60, \mathrm{f}_{\mathrm{cr}}=3000 \mathrm{~Hz}\right)$} \\
\cline { 3 - 4 } & & \multicolumn{2}{c}{ Phase Disposition (Carrier Signal) } \\
\cline { 3 - 4 } Sr. & Inverter & (Modulating & Third Harmonic Injection \\
No. & Configuration & Signal) $\mathrm{m}_{\mathrm{a}}=1.8$ & (Modulating Signal) $\mathrm{m}_{\mathrm{a}}=1.2$ \\
\hline 1 & Cascade Connected & 8.51 & 8.66 \\
2 & Diode Clamped & 8.40 & 8.57 \\
3 & Flying Capacitor & 8.51 & 8.66 \\
\hline
\end{tabular}

(b) 11 Level Multilevel Inverter $\left(\mathrm{m}_{\mathrm{f}}=60, \mathrm{f}_{\mathrm{cr}}=3000 \mathrm{~Hz}\right)$

\begin{tabular}{llll}
\hline & & \multicolumn{2}{c}{ Phase Disposition (Carrier Signal) } \\
\cline { 3 - 4 } Sr. & Inverter & $\begin{array}{l}\text { Pure Sinusoidal } \\
\text { (Modulating }\end{array}$ & Third Harmonic Injection \\
No. & Configuration & Signal) $\mathrm{m}_{\mathrm{a}}=1.8$ & (Modulating Signal) $\mathrm{m}_{\mathrm{a}}=1.2$ \\
\hline 1 & Cascade Connected & 5.88 & 5.20 \\
2 & Diode Clamped & 5.68 & 4.94 \\
3 & Flying Capacitor & 5.88 & 6.26 \\
\hline
\end{tabular}
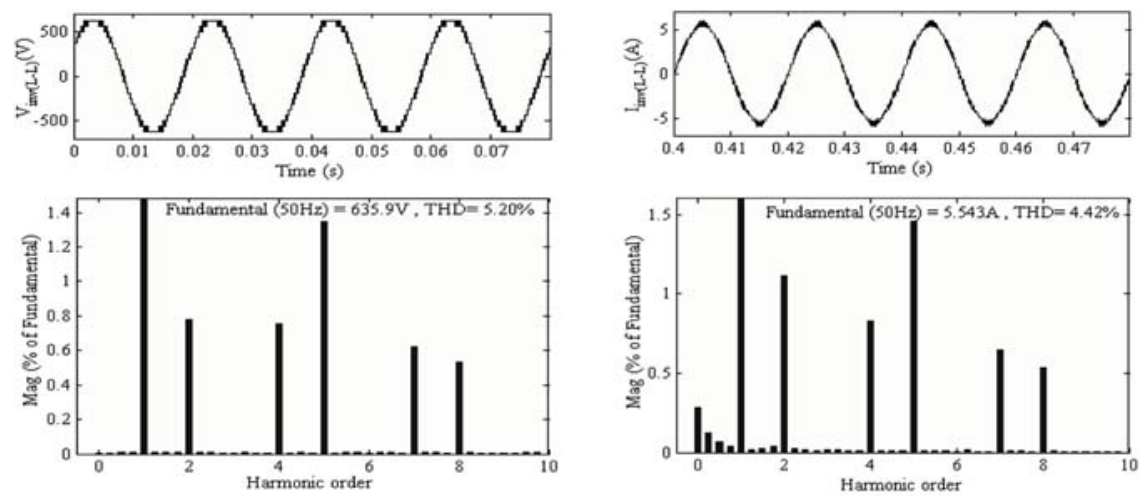

(a)

(b)

Figure 6 Waveforms and harmonic spectra of 11 level cascade H-bridge inverter with THI modulating signal (a) Inverter output line voltage (b) Inverter output line current.

\subsection{Distributed Power Generation System (DPGS) Feeding Interconnected Load with and without Grid Connection}

This inverter is feeding AC supply to the load which is connected with the grid. Here the distributed power generation system is operated in three different modes. In first and second mode, the system is under hybrid load 

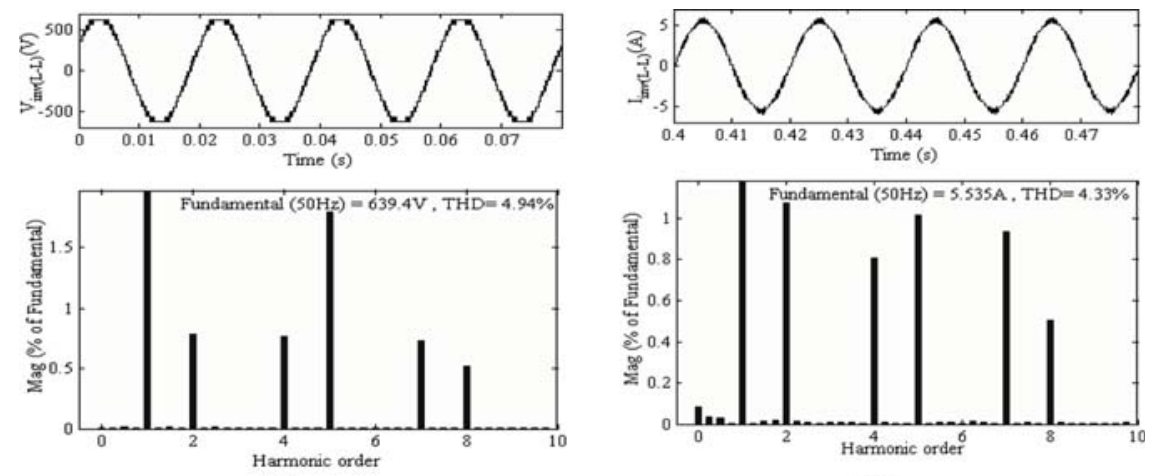

(a)

(b)

Figure 7 Waveforms and harmonic spectra of 11 Level diode clamped inverter with THI modulating signal (a) Inverter output line voltage (b) Inverter output line current.
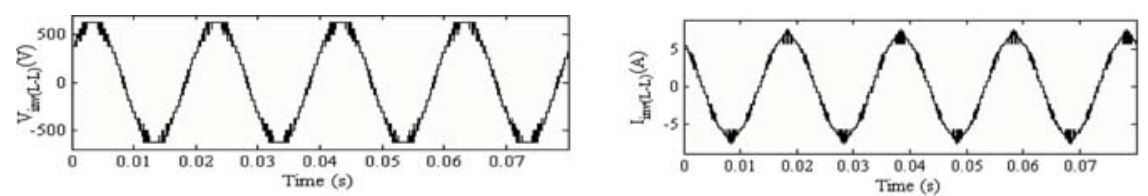

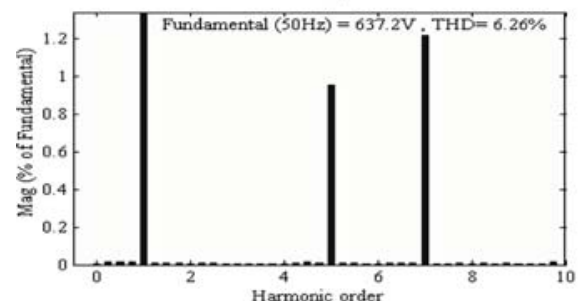

(a)

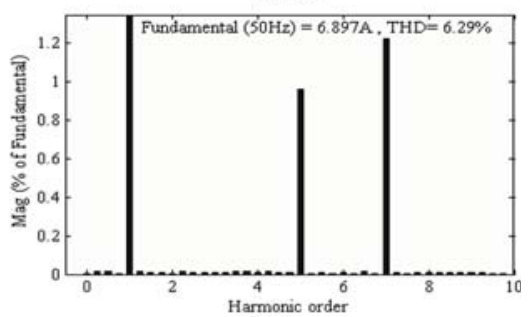

(b)

Figure 8 Waveforms and harmonic spectra of 11 level flying capacitor inverter with THI modulating signal (a) Inverter output line voltage (b) Inverter output line current.

mode of operation, where normal grid supply and fuel cell fed Inverter are interconnected such that power is shared between them. In third mode, power is fed to the load in isolated mode that is without grid connection.

It is observed from Figure 9 and Figure 10 in first mode and second mode, it is found that at $0.25 \mathrm{sec}$, there are variation in the waveforms due to turning on the circuit breaker at period of $0.25 \mathrm{sec}$. Between the Grid and fuel cell fed inverter a circuit breaker is connected which switches on at $0.25 \mathrm{sec}$ to 


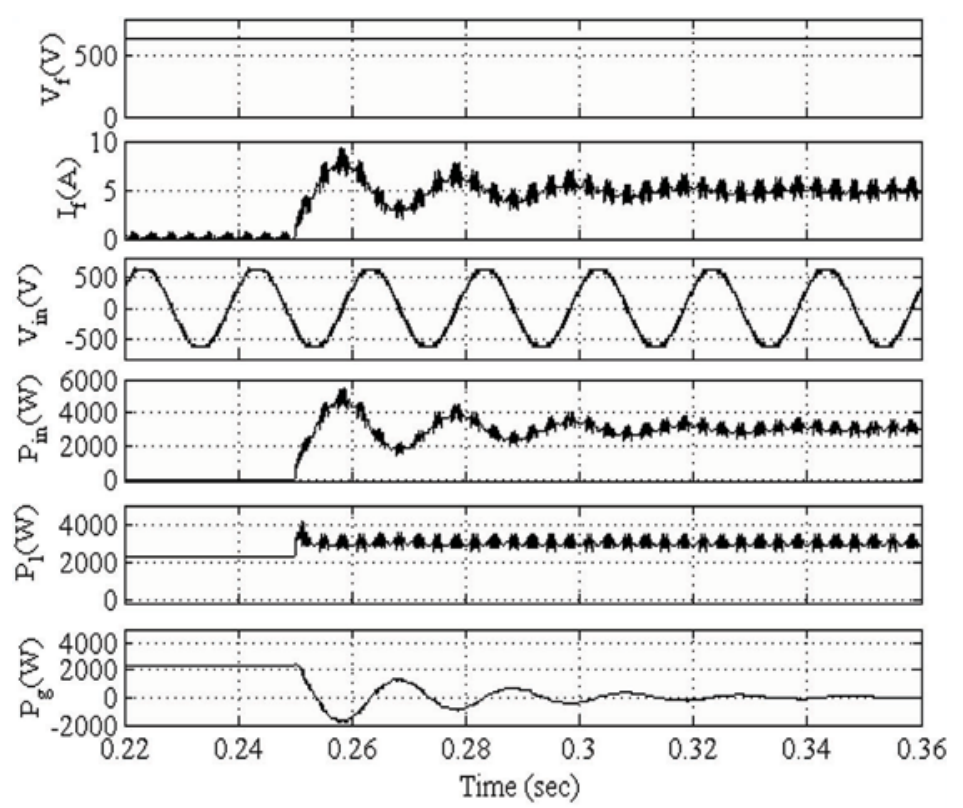

(a)
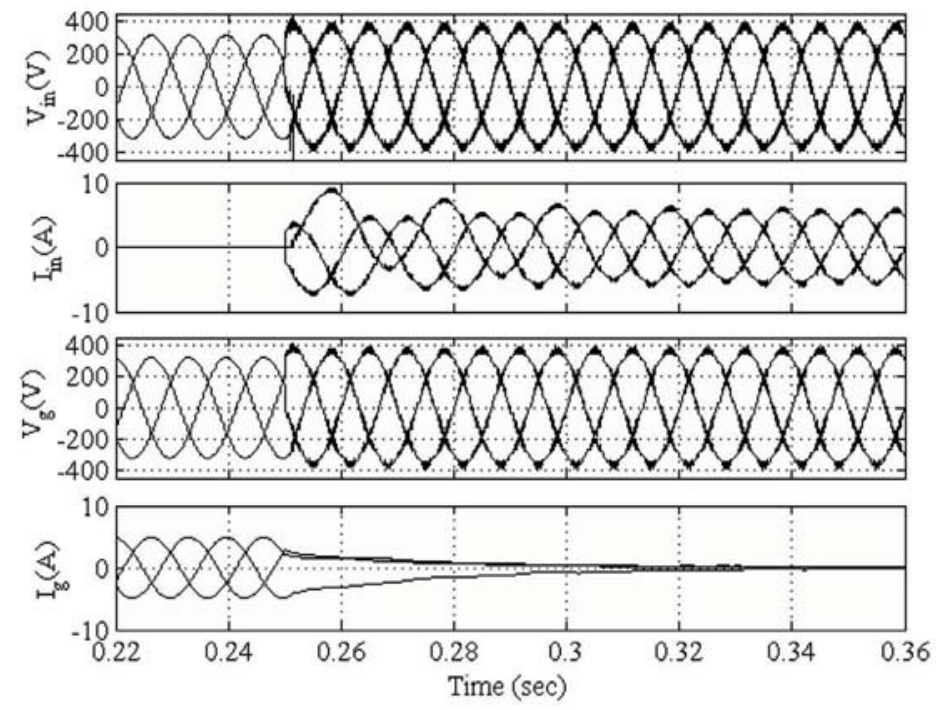

(b)

Figure 9 When Fuel Cell wholly feeds the load connected to grid (a) Power variations in inverter, load and grid. (b) Voltage and current variations in inverter and Grid [mode-1]. 


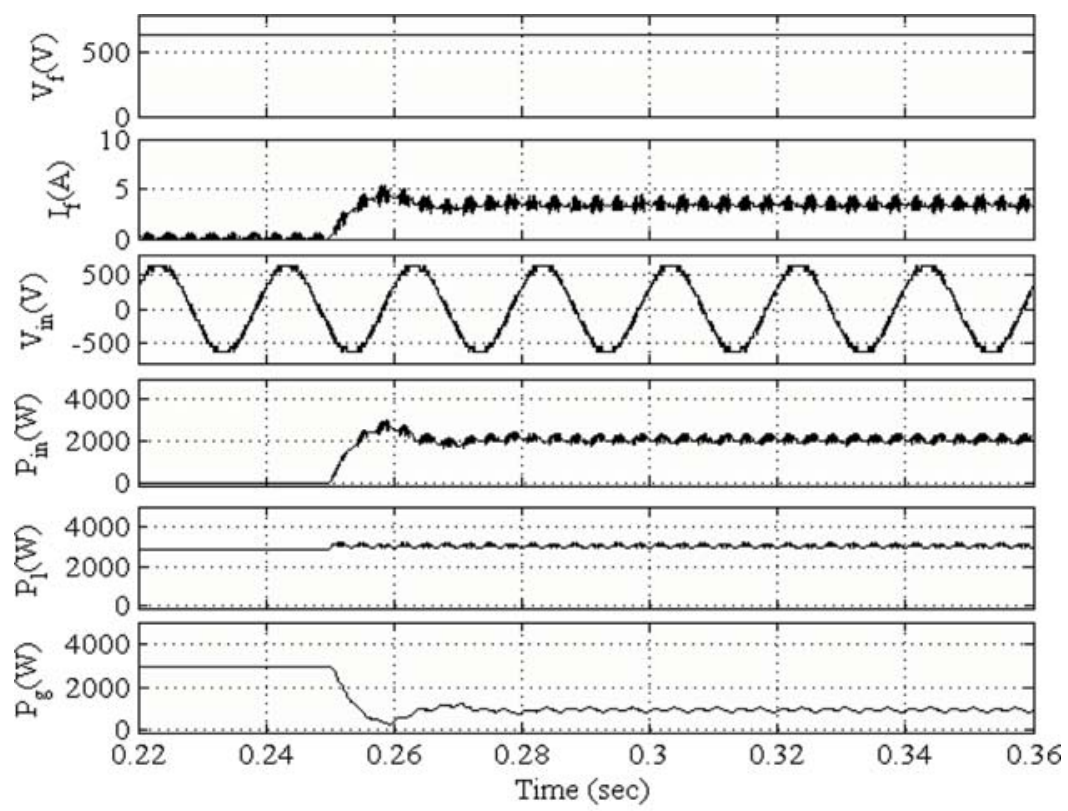

(a)

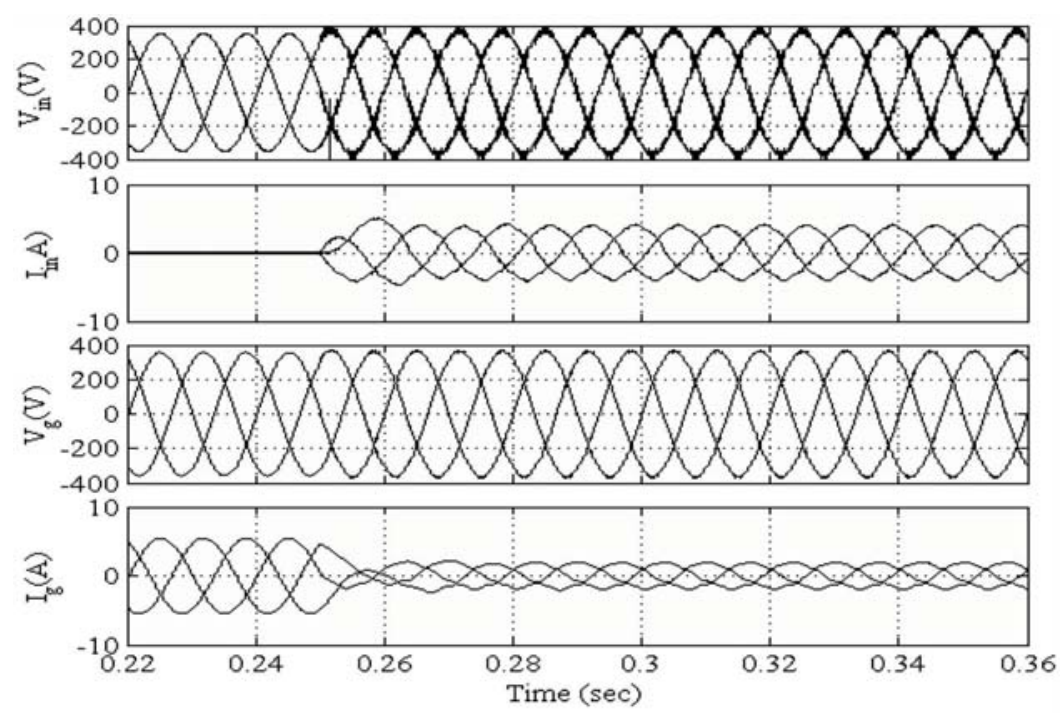

(b)

Figure 10 When fuel cell shares the load with grid connected system (a) Power variations in Inverter, Load and Grid. (b) Voltage and current variations in Inverter and Grid [mode-2]. 
see the variations in the system if suddenly the fuel cell fed power is connected to the grid. Here, it is considered that the system has consumer load of $\mathrm{P}_{\mathrm{L}}=$ $3000 \mathrm{~W}$ connected to the systems. Figure 9(a) shows the power variation in the system at inverter $\left(\mathrm{P}_{\text {in }}\right)$, load $\left(\mathrm{P}_{1}\right)$ and grid $\left(\mathrm{P}_{\mathrm{g}}\right)$ in first mode of operation. As it can be seen in the first mode, from starting to $0.25 \mathrm{sec}$ the grid supplies power $\left(\mathrm{P}_{\mathrm{g}}\right)$ of $2000 \mathrm{~W}$ to its ability but after $0.25 \mathrm{sec}$ the fuel cell fed inverter feeds the complete power $\left(\mathrm{P}_{\text {in }}\right)$ of $3000 \mathrm{~W}$ resulting that the power supplied by grid $\left(\mathrm{P}_{\mathrm{g}}\right)$ becomes zero. Figure 9 (b) shows the variation in voltage $\left(\mathrm{V}_{\text {in }}\right)$ and current $\left(\mathrm{I}_{\mathrm{in}}\right)$ of inverter and grid $\left(\mathrm{V}_{\mathrm{g}}\right.$ and $\left.\mathrm{I}_{\mathrm{g}}\right)$ for first mode of operation.

Similarly Figure 10(a) shows the power variation in the system at inverter $\left(\mathrm{P}_{\text {in }}\right)$, load $\left(\mathrm{P}_{1}\right)$ and grid $\left(\mathrm{P}_{\mathrm{g}}\right)$ for second mode of operation. In second mode, the considerable increase in power delivering capacity is made to increase in such a way that the fuel cell fed inverter feeds $2000 \mathrm{~W}$ of power and remaining $1000 \mathrm{~W}$ power is supplied from grid side power $\left(\mathrm{P}_{\mathrm{g}}\right)$. Figure $10(\mathrm{~b})$ shows the variation in voltage and current of inverter and grid for second mode of operation. Figure 11 shows the waveform of voltage $\left(\mathrm{V}_{\mathrm{l}}\right)$, current $\left(\mathrm{I}_{\mathrm{l}}\right)$ and
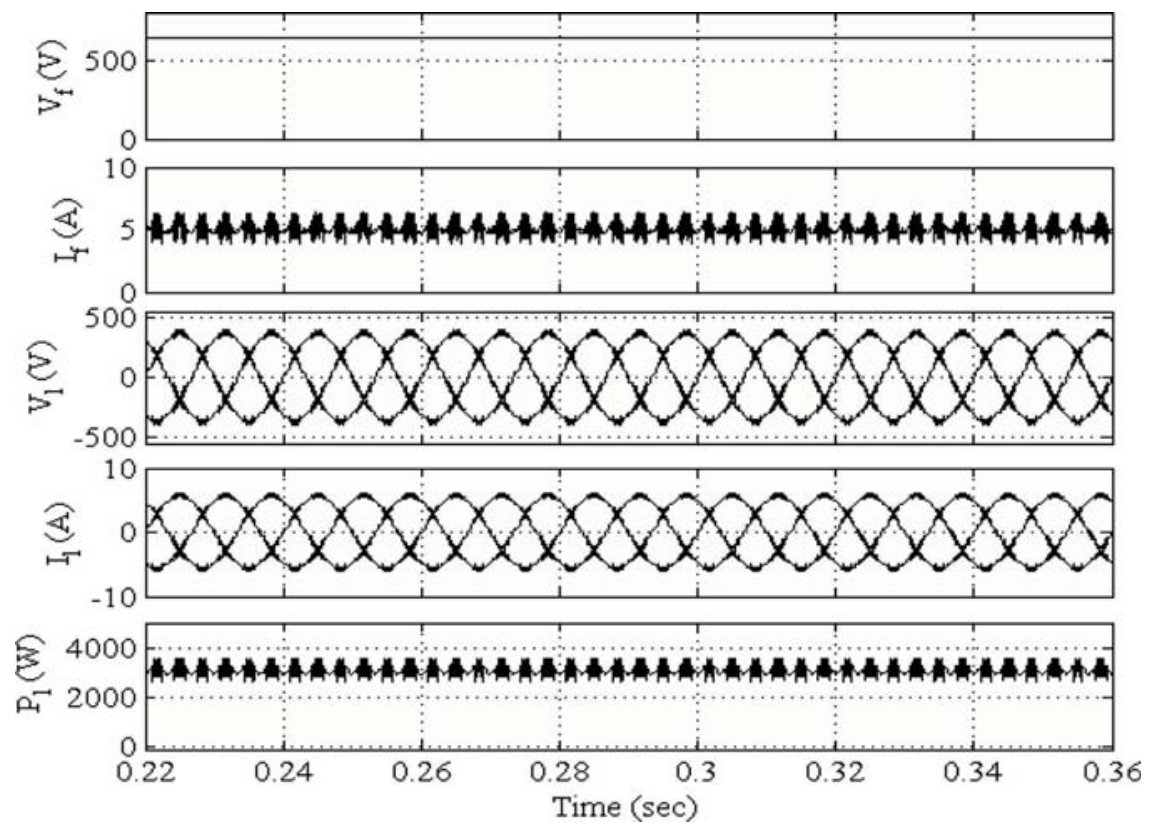

Figure 11 Voltage, current and power spectra when fuel cell connected to isolated load [mode-3]. 
power $\left(\mathrm{P}_{1}\right)$ at load for third mode of operation which is constant without any variation in its waveform. Overall, when this type of energy systems have the capability of powering houses and small scale industries without any grid correction and many other people can get advantages of that extra grid power in hybrid system. Any surplus power that is produced can return back into the grid. When this system is not accessible or not able to produce power then electricity from the grid is effective for connected loads. It eliminates the expenses of storage batteries.

\section{Conclusion}

Fuel cell is considered as an one of the most stirring energy technologies for future, due to its high efficiency and neatness. A fuel cell operates like a battery and it needs an external fuel. Here electricity is generated by oxidizing the fuel cell. These fuel cells are presently available in the market and solid oxide fuel cell (SOFC) is suitable fuel cell for ships and household. These fuel cells are most appropriate for auxiliary power units like in massive trucks and ships or as a stationary power generating units for central power stations.

Three phase multilevel inverter (MLI) topologies and carrier based control are discussed and 11 level diode clamped MLI topology is found more effective in term of power quality. The 11 level diode clamped MLI topology is simulated in isolated mode as well as grid connected supply with three phase consumer load. The power supply from the fuel cell and grid through the three phases MLI is studied in details with consideration of power quality terms. The output of the inverter is improved by using Third harmonic injection as reference signal which gives 4.94\% THD of the voltage waveform that is significantly less compared to the widely used three phase six pulse inverters which has the THD of nearly $31 \%$ or higher. The introduction of this type of distributed power generation system is found to be suitable for three phase consumer loads in hybrid supply system or isolated system.

\section{Appendix}

A1. Fuel Cell supply source details [2]: Temperature $=303 \mathrm{~K}, \mathrm{H}_{2}$ Pressure $=$ $2.5 \mathrm{Atm}, \mathrm{O}_{2}=5 \mathrm{Atm}$, Nernst Voltage $=1.25 \mathrm{~V}$, One cell voltage $=1.11 \mathrm{~V}$, Number of cells $=574$, Fuel cell O/P Voltage $=641 \mathrm{~V}$. 
A2. Diode Clamped, Cascade and Flying Capacitor Inverter: Output voltage $\left(\mathrm{V}_{\mathrm{pp}}\right)=621 \mathrm{~V}$, supply frequency $(\mathrm{f})=50 \mathrm{~Hz}$, Switching frequency $\left(\mathrm{f}_{\mathrm{S}}\right)=3000 \mathrm{~Hz}$, Resistive consumer load $=3000 \mathrm{~W}$.

A3. Three phase Grid supply: Source Impedance: Resistance $\left(\mathrm{R}_{\mathrm{S}}\right)=0.05 \Omega$, inductance $\left(\mathrm{L}_{\mathrm{S}}\right)=1 \mathrm{mH}$, Phase to phase voltage $=1000 \mathrm{~V}$, Supply frequency $(\mathrm{f})=50 \mathrm{~Hz}$; Transformer rating: $1000 \mathrm{VA}$ (mode-1) and 6000 $\mathrm{VA}$ (mode-2), $\mathrm{V}_{\text {primary }}=1000 \mathrm{~V}, \mathrm{~V}_{\text {secondary }}=440 \mathrm{~V}$.

\section{References}

[1] Zhou, D., Gao, F., Breaz, E., Ravey, A., Miraoui, A., and Zhang, K. (2016). Dynamic phenomena coupling analysis and modeling of proton exchange membrane fuel cells. IEEE Trans. Energy Convers. 31, 1399-1412.

[2] Larminie, J., and Dicks, A. (2003). Fuel Cell Systems: Explained, 2nd Edn. New York, NY: John Wiley and Sons Ltd.

[3] Natsheh, E. M., Natsheh, A. R., and Albarbar, A. (2013). Intelligent controller for managing power flow within standalone hybrid power systems. IET Sci. Meas. Technol. 7, 191-200.

[4] Dincer, I. (2008). Hydrogen and fuel cell technologies for sustainable future. Jordan J. Mech. Ind. Eng. 2, 1-14.

[5] Jain, S., Jiang, J., Huang, X., and Stevandic, S. (2012). Modeling of fuelcell-based power supply system for grid interface. IEEE Trans. Ind. Appl. 48, 1142-1153.

[6] Aguilar, C., Vazquez, A., Canales, F., and Gordillo, J. (2016). Integrated DC-AC converter as power conditioner for fuel cell based system. IEEE Latin Am. Trans. 14, 2107-2113.

[7] Alepuz, S., Busquets-Monge, S., Bordonau, J., Gago, J., Gonzalez, D., and Balcells, J. (2006). Interfacing renewable energy sources to the utility grid using a three-level inverter. IEEE Trans. Ind. Electron. 53, 1504-1511.

[8] Rodriguez, J., Lai, J. S., and Peng, F. Z. (2002). Multilevel inverters: a survey of topologies, controls, and applications. IEEE Trans. Ind. Electron. 49, 724-738.

[9] Dargahi, S., Babaei, E., Eskandari, S., Dargahi, V., and Sabahi, M. (2014). Flying-capacitor stacked multicell multilevel voltage source inverters: analysis and modelling. IET Power Electron. 7, 2969-2987. 
[10] Patel, D., Saravanakumar, R., Ray, K. K., and Ramesh, R. (2011). “A review of various carrier based PWM methods for multilevel inverter," in Proceedings of the India International Conference on Power Electronics 2010 (IICPE2010), New Delhi, 1-6.

[11] Carpita, M., Marchesoni, M., Pellerin, M., and Moser, D. (2008). Multilevel converter for traction applications: small-scale prototype tests results. IEEE Trans. Ind. Electron. 55, 2203-2212.

[12] Geethalakshmi, B., Dananjayan, P., and DelhiBabu, K. (2008). "A Combined Multipulse-Multilevel Voltage Source Inverter Configuration for STATCOM Applications," in Proceedings of the 2008 Joint International Conference on Power System Technology and IEEE Power India Conference, New Delhi, 1-5.

[13] Escalante, M. F., Vannier, J. C., and Arzande, A. (2002). Flying capacitor multilevel inverters and DTC motor drive applications. IEEE Trans. Ind. Appl. 49, 809-815.

[14] Shukla, A., Ghosh, A., and Joshi, A. (2008). Control schemes for DC capacitor voltages equalization in diode-clamped multilevel inverter based DSTATCOM. IEEE Trans. Power Deliv. 23, 1139-1149.

[15] Nehrir, M. H., and Wang, C. (2009). Modeling and Control of Fuel Cells Distributed Generation Applications. Hoboken, NJ: John Wiley and Sons.

[16] Tenfen, D., Finardi, E. C., Fernandez, V. S. S., and Ober, T. (2014). "An improved modeling for microturbines and fuel cells to the energy management problem of microgrids," in Proceedings of the 2014 Power Systems Computation Conference, Wroclaw, 1-7.

[17] Kumar, J. (2012). THD analysis for different levels of cascade multilevel inverters for industrial applications. Int. J. Emerg. Technol. Adv. Eng. 2.

[18] Dincer, I. (2002). Technical, environmental and exergetic aspects of hydrogen energy systems. Int. J. Hydr. Energy 27, 265-285.

[19] Midilli, A., Ay, M., Dincer, I., and Rosen, M. A. (2005). On hydrogen and hydrogen energy strategies-I- current status and needs. Renew. Sustain. Energy Rev. 9, 291-307.

[20] Baretto, L., Makihira, A., and Riahi, K. (2003). The hydrogen economy in the 21 st century: a sustainable development scenario. Int. J. Hydr. Energy 28, 267-284.

[21] Adams, A. M., Bacon, F. T., and Watson, R. G. H. (1963). Fuel Cells. New York, NY: Academic Press.

[22] Wu, B. (2006). High-Power Converters and AC Drives. Hoboken, NJ: John Wiley and Sons. 


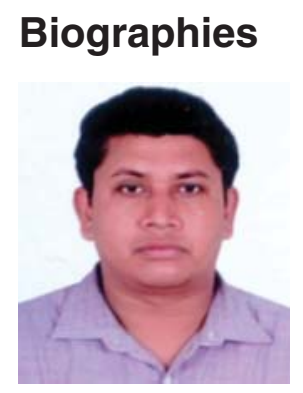

Sabha Raj Arya received Bachelor of Engineering (Electrical Engineering) degree from Government Engineering College Jabalpur, in 2002, Master of Technology (Power Electronics) from Motilal National Institute of Technology, Allahabad, in 2004 and Ph.D. degree from Indian Institute of Technology (I.I.T.) Delhi, New Delhi, India, in 2014. He is joined as Assistant Professor, Department of Electrical Engineering, Sardar Vallabhbhai National Institute of Technology, Surat. His fields of interest include Design of power electronics converter, power quality, application of power filters and distributed power generation based on fuel cell, solar wind etc.

He received Two National Awards namely INAE Young Engineer Award from Indian National Academy of Engineering, POSOCO Power System Award from Power Grid Corporation of India in the year of 2014 for his research work. He is also received Amit Garg Memorial Research Award2014 from I.I.T. Delhi from the high impact publication in a quality journal during the session 2013-2014. He is a Senior Member of the Institute of Electrical and Electronics Engineers (IEEE).

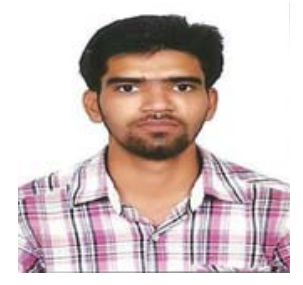

Nunsavath Sharath Kumar received Bachelor of Engineering (Electrical and Electronics Engineering) degree from Jawaharlal Nehru Technological University, Hyderabad in 2014. At present, he is doing his Master degree in Power Electronics and electrical drives from Sardar Vallabhbhai National Institute of Technology, Surat (India). His fields of interest include design of power electronics converters, and its application in electrical Engineering, distributed power generation. 
